\title{
Familieråd - metodetilpassing til samisk sosialt arbeid
}

\section{Samandrag}

I denne artikkelen diskutera vi tilpassing av familieråd til ein samisk kontekst. Studien bygg på intervju med sosialarbeidarar i samiske områder. Vi finn at familierådsmodellen sitt teoretiske grunnlag bør tematisere samisk storfamilie, samiske kommunikasjonsformer, samiske ideal for barnet si deltaking og familierådskoordinator sin lokale tilknyting. Det teoretiske grunnlaget må diskutere at lokalsamfunn, familiar og enkeltindivid har ulike samisk identitetar. Det teoretiske grunnlaget bør vidare sjå familieinvolvering i relasjon til fornorsking av det samiske folk og korleis dette kan påverke samspelet innanfor ein familie samt mellom familiar og hjelpeapparat.

Nøkkelord: Familieråd, samisk sosialt arbeid, kulturelt relevante metodar

\section{Abstract}

This article discuss adjustment of the social work model Family Group Conference (FGC) to a Sami context. The study base on interviews with social workers in Sami communities. We find that the theoretical foundation of FGC ought to discuss the Sami extended family, Sami communication forms, Sami ideals for child rearing, and the FGC coordinators local knowledge. The theoretical foundation should discuss 'family involvement' in relation to the norwegianization of the Sami people - and how the norwegianization can influence on the relation within a family, in addition to the relation between family and welfare agency. 
Keywords: Family Group Conference, indigenous social work, Sami social work, cultural relevant methods.

\section{Innleiing}

Denne artikkelen er basert på ein studie i samarbeid med Regionalt samisk kompetansesenter (RESAK), ved Barne-, ungdoms-, og familieetaten, region Nord (Bufetat, region Nord).

RESAK ønska å anvende familierådsmodellen i samisk sosialt arbeid og starta eit implementeringsprosjekt for bruk av familieråd med samiske familiar i 2013. I den forbindelse initierte RESAK eit samarbeid med vår forskingsgruppe ved Regionalt kunnskapssenter for barn og unge - Nord. RESAK etterspurte meir kunnskap om familieråd i ein Samisk kontekst. Vår forskargruppe jobba på denne tida med eit forskingsprosjekt for å evaluere den nasjonale satsinga på familieråd i fosterheimsarbeid i regi av Barne-, ungdoms-, og familiedirektoratet (Bufdir) (Sending, Strandbu, \& Thørnblad, 2015). I samarbeid med RESAK etablerte vi eit delprosjekt til forskingsprosjektet med mål om å få meir kunnskap om familierådsmodellen til bruk i samiske samfunn. Dette prosjektet vart utarbeida som ein komparativ studie av sosialt arbeid i samiske samfunn i Norge og native amerikanske samfunn i Montana, USA (Nygård, 2018).

Familieråd er ein modell til bruk i sosialt arbeid med barn og familie. Modellen legg til rette for at familie og storfamilie blir involvert når det skal fattast sluttingar om eit barn sin situasjon og kva tiltak som skal settast i verk (The Maori Perspective Advisory Committee, 1998/2001). Modellen vart utvikla av Maorifolket på New Zealand. Dei opplevde at deira tradisjon for å inkludere storfamilien, og å sjå barnet som del av eit fellesskap, ikkje vart vektlagt i møte med barnevernet (Love, 2002; The Maori Perspective Advisory Committee, 1998/2001). I løpet av 1990 talet har familierådsmodellen blitt implementert til bruk i ulike delar av sosialt arbeid i omtrent 30 land (Havnen \& Christiansen, 2014). I Norge har 
familieråd blitt implementert først og fremst til bruk innanfor barnevernet, men også til bruk i familievern.

Familieråd har si oppringing i eit urfolk sine tradisjonar, og modellen har blitt intendert implementert til bruk i andre urfolkssamfunn (Ban, 2005; Drywater-Whitekiller, 2014; Gilbert, 2013; Henriksen, 2004b; Hill, 2005; Holkup, Salois, Tripp-Reimer, \& Weinert, 2007; Marcynyszyn et al., 2012). Norske myndigheter har hatt ein intensjon om å implementere denne modellen til bruk i sosialt arbeid i samiske samfunn, blant anna er den oversett til samisk (Bufdir, 2013). På tross av dette er det gjennomført svært få familieråd med samiske familiar (Sending et al., 2015, s. 36). Vår studie er dermed ikkje ein empirisk studie av praktisk bruk av familieråd, men ein studie av sosialarbeidarar sine erfaringar med involvering av familie og korleis dei ser dette som ein kulturelt egna praksis.

Familierådsmodellen vart utvikla etter ein lenger og omfattande prosess blant Maoriane leia av leiarar i Maori samfunnet (The Maori Perspective Advisory Committee, 1998/2001). Då modellen vart implementert til Norge vart den tilpassa til den norske konteksten (Falck, 2009; Horverak, 2009). Ved implementering i den samiske konteksten har det ikkje vore ein tilsvarande modelltilpassing til samiske samfunn. Dette er utgangspunktet for vår analyse. Med utgangspunkt i sosialarbeidarar i samiske samfunn sine erfaringar med familieråd og familieinvolvering spør vi korleis familieråd kan gjerast relevant i ein samisk kontekst. I denne artikkelen analysera vi dei teoretiske byggeklossane i familieråd opp mot erfaringar med sosialt arbeid i samiske samfunn. 


\section{Teori}

\section{Familieråd}

På 1980 talet vaks det fram ein bevegelse der leiarar blant Maoriane etterspurte eit sosialt velferdssystem som kjempa med heller enn mot Maori samfunna (Love, 2000). Myndigheitene i New Zealand etablerte ein komité for å utgreie korleis sosialt arbeid kan utøvast frå eit Maori perspektiv. Medlemmane i komiteen reiste gjennom New Zealand og snakka med tusenvis av menneske frå Maoriane. Dei studerte historia til Maoriane, i tillegg til dagens politikk og praksisar innanfor sosialt arbeid. Komiteen sin rapport konkludera med at sosialt arbeid i større grad må inkludere familie, tribe og lokalsamfunn i arbeid med barn og familie (The Maori Perspective Advisory Committee, 1998/2001). Utviklinga av familierådsmodellen er eit konkret utfall av denne rapporten (Love, 2002).

Involvering av utvida familie i problemløysing er eit sentralt teoretisk prinsipp i familieråd. Modellen er tufta på ein ide om brukarmedverknad, der brukaren skal vere med å definere problemet og kva hjelp som trengs (Slettebø, 2000). Vidare legg modellen stor vekt på å rette opp familierelasjonar og familieband (Connolly, 2009; Meyer, 1998, 2002; Pranis, 2015). Det er vanlig å vise til fem hjørnesteiner i familieråd; 1) Deltaking frå den utvida familie. 2) Familien si eigentid for drøfting og problemløysing. 3) Ein uavhengig koordinator hjelp familien å planlegge og gjennomføre familierådet. 4) Familien utformar sin eigen handlingsplan. 5) Familierådet legg til rette for at barnet deltar (Havnen \& Christiansen, 2014; Strandbu, 2007). Familieråd er ein modell for å bringe familien saman for i fellesskap å løyse dei utfordringane familien har.

Sidan familieråd har sitt utspring frå Maorifolket sine tradisjonar blir modellen ofte vist til som relevant for andre urfolkssamfunn (Henriksen, 2004b; Holkup et al., 2007; Maxwell, 
2008; Pennell \& Anderson, 2005; Zehr, 2002). I ein meta-syntese spør Nygård and Saus (2019) om familieråd er ein kulturelt egna modell også utanfor New Zealand. Syntesen viser at det ikkje er modellen i seg sjølv som er kulturelt egna, det er modellen sitt teoretiske rammeverket som bær på potensiale for kulturelt adekvat sosialt arbeid. Modellen må derimot tilpassast den lokale konteksten for å sikre kulturell relevans.

\section{Dei samiske samfunn}

Samane er Nord-Europas urfolk, og har sine landområder i Norge, Sverige, Finland og Russland. Samisk landområde blir kalla Sápmi. I Norge, bur den samiske befolkninga over heile landet, men majoritetsbefolkninga finn vi i dei nordlige delane av landet, nord for Saltfjellet (SSB, 2019). Det samiske folk har ei rekke felles tradisjonar og kulturmarkørar, og blir definert som eit folk (Nordisk Samekonferanse, 1980). Det samiske folk er likevel ei kulturelt og språklig mangfaldig gruppe (Eidheim, 1971; Pedersen \& Nyseth, 2015). Eit tydelig eksempel på denne pluraliteten er tre ulike samiske språk, innanfor den norske delen av Sápmi. Dankertsen (2014) viser eit mangfald av ulike måtar å skape samisk identitetar på mellom det norske og det samiske. I denne artikkelen snakkar vi om dei samiske samfunna, for å understreke mangfaldet i samiske samfunn og samiske kulturar.

Den samiske befolkning har vore utsatt for ein omfattande fornorskingspolitikk. Denne politikken var strategisk og systematisk retta inn mot å gjere den samiske befolkninga norsk (Minde, 2005). Gjennom fornorskingspolitikken har det samiske folk mista store delar av språk, kultur og land (Bjørklund, 1985; Sárgon, 2007; Vars, 2017). Fornorskingspolitikken frå den norske stat har hatt ulik verknad, og ulik styrke, i ulike delar av Sápmi. Med ulik effekt av fornorsking i ulike lokalsamfunn, blir også re-vitaliseringsprosessane ulike. Behovet for ulik re-vitaliseringsprosess i ulike samiske samfunn blir tematisert av (Grenersen, 1995) sin studie av re-vitalisering i Marka- og Lulesamisk områder. Mangfaldet i dei samiske samfunn krev 
ein kontekstuell tilnærming når ein ønskjer å tilpasse sosialt arbeid til samiske kulturar (Saus, 2008).

\section{Samisk storfamilie}

I forskingslitteratur om samiske forhold blir den utvida familie ofte framheva som ein viktig del av samisk kultur (Balto, 1997; Henriksen, 2004a; Juuso, 2000; Nystad, Spein, \& Ingstad, 2014). I tradisjonelle samiske kulturar er både biologisk slekt, og slekt basert på sosiale relasjonar viktig (Henriksen, 2004a). Biologisk slekt inkludera mødrer, ferde, søsken, tanter, onklar, besteforeldre, søskenbarn, og tremenningar. Slekt basert på sosiale relasjonar er rituelle slektningar, som fadderar, namnesøsken eller skulesøsken (Erke, 1986). Slektskapet er eit system av sosiale relasjonar med ansvar og plikter overfor kvarandre (Henriksen, 2004a). Strukturen i organisering, ansvar og plikter knytt til ulike roller og relasjonar i den samiske storfamilien skil seg frå den norske familie strukturen (Erke, 1986). Det blir forventa ein nærleik og respekt mellom slektningar, både som utøvarar av sosial kontroll, omsorg og opplæringsfunksjonar (Balto, 1997). V. Nergård (2005) kallar dette fleirforeldre prinsippet. Det er fleire vaksne rollemodellar som står barnet nært og som har ei rolle i oppdragelse og ivaretaking.

Kolonisering, modernisering og urbanisering av samiske samfunn har ført til at det samiske storfamiliesystemet er i endring (Erke, 1986). Andre etniske grupper i Norge har også gått igjennom ein modernisering og urbanisering av familieband. Likevel skil endringa i familieband i dei samiske samfunna seg frå endring i familieband for etnisk norske. Dette fordi endringa kjem som eit resultat av tvungen assimilering, i tillegg til moderisering og urbanisering. Tap av språk, kultur og identitet er for mange i dag eit skambelagt tema (Johansen, 2004; Minde, 2005). Jens-Ivar Nergård (1992) introduserer omgrepet kulturell 
smerte. Omgrepet beskriv ein skam som kan bli påført menneske når samisk språk og kultur blir gjort usynlig (J.-I. Nergård, 1994). Minde (2005) bruker omgrepet 'kulturelle smerte' om dei psykososiale konsekvensane av assimileringa. Tap av familieband og kulturell tilknyting kan vere ein del av denne kulturelle smerten.

\section{Kommunikasjonsformer}

Samiske kommunikasjonsformer er indirekte, der tausheit, kroppsspråk og metaforar har ein sentral plass (Boine, 2005; Bongo, 2012; Dagsvold, Møllersen, \& Stordahl, 2015). I samiske samfunn er det mange som opplever at tema som psykiske problem, vald, overgrep, eller rus er tabubelagte (Dagsvold et al., 2015; Kemi, 2000). For nokon blir desse tema ikkje satt ord på i det heile, medan det for andre blir halde innanfor familien (Dagsvold et al., 2015; Øverli, Bergman, \& Finstad, 2017). Boine (2005) viser korleis Bálddalagaid (side-om-side) kommunikasjon, og gulahallat (evne til å lytte og forstå andre) kommunikasjon, er viktige verdiar i samisk barneoppdragelse. Desse kommunikasjonsformene verdset indirekte kommunikasjon.

I ein studie av opplevingar av å vokse opp i eit samisk samfunn når mor eller far rusar seg, finn Kemi (2000) at barna ofte opplever at fellesskapet i storfamilien ikkje stiller opp. Deira opplevingar var at dei vaksne i familien beskyttar den som har rusproblem heller enn å beskytte barnet. I ein studie om vald og overgrep i samiske samfunn peikar Øverli et al. (2017) på at tenesteapparatet kan vegre seg for å spørje om vanskelege tema i møte med samiske brukarar. Dette er enten fordi dei er redde for å krenke eller av mangel på kultur- og språkkompetanse. Samiske barn har på lik linje med andre barn rett å få hjelp frå det offentlege når dei er utsett for omsorgssvikt. For sosialt arbeid er derfor forståing for tabubelagte tema, samt dei samiske kommunikasjonsformene viktig. 
Som eit resultat av historisk undertrykking er det i dag ein grad av misstillit mellom samisk befolkning og norske offentlige myndigheiter (Nordland Politidistrikt, 2017; Saus, Salamonsen, Douglas, Hansen, \& Thode, 2018, 98). Sosialarbeidar er ein representant for den norske velferdsstaten. Dersom ein opplever at samiske brukarar trekk seg unna velferdsstaten sine tenester kan dette grunne i relasjonen mellom den samiske befolkning og den norske stat.

\section{Samisk sosialt arbeid}

I urfolkssamfunn verda over er der ein pågåande debatt om korleis sosialt arbeid kan tilpassast lokale forhold (Gray, Coates, Yellow Bird, \& Hetherington, 2016; Sinclair, 2004). Denne debatten er også pågåande innanfor sosialt arbeid i samiske områder (Eidheim \& Stordahl, 1998; Saus, 2008; Tronvoll, Moe, \& Henriksen, 2004). I ein kunnskapsoppsumering for barnevern i samiske områder blir det peika på at der føreligg kunnskap om samiske praksisformer, verdiar og kunnskapsformer. Likevel er der utvikla lite kunnskap om korleis dei samiske verdiane skal omsettast til praktisk sosialt arbeid overfor samiske barn og unge (Saus \& Boine, 2008). Sosialarbeidarar i samiske områder etterlys fagspråk og fagutvikling tilpassa samiske kontekstar (Saus et al., 2018).

Forsking innanfor helse- og sosialfag hevdar at det er viktig å inkludere storfamilien når ein møter ein samisk pasient eller klient (Langås-Larsen et al., 2018; Wilhelmsen, 2010). For å tilpasse sosialt arbeid til samisk kultur blir involvering av storfamilien derfor framheva som eit viktig aspekt (Hanssen, 2004; Henriksen, 2004b). Dette er bakteppet for at vi i denne artikkelen ser spesielt på korleis metodar for familieinvolvering kan tilpassast den samiske konteksten. 


\section{Profesjonell nærleik}

Sosialarbeidarar i samiske samfunn i Norge og native amerikanske samfunn i Montana, USA, løftar fram lokalkunnskap som viktig for å gjere godt sosialfaglig arbeid. Basert på desse forteljingane veks det teoretiske omgrepet profesjonell noerleik fram (Nygård, 2018). Når sosialarbeidarane i samiske samfunn snakkar om tilknyting til og kunnskap om lokalsamfunnet er det tre tema som merkar seg ut; 1) personlig kontakt med folk i lokalsamfunnet, 2) innsikt i ulike måtar å identifisere seg som samisk, 3) forståing for ulike måtar å identifisere seg som samisk i ulike lokalmiljø. I forteljingane frå sosialarbeidarane i samiske samfunn er 'kunnskap om den lokale dynamikken’ eit nøkkel element for å tilby kulturelt adekvate sosiale tenester.

\section{Metodologi og metode}

Denne artikkelen bygg på materiale samla inn for ein kvalitativ samanliknande studie av sosialt arbeid i urfolkssamfunn i Norge og i Montana, USA. Den komparative delen av studien spør etter relevansen av involvering av familie og lokalsamfunn i sosialt arbeid i samiske samfunn i Norge og native amerikanske samfunn i Montana sjå (Nygård, 2018). Denne artikkelen bygg på intervju med sosialarbeidarar i samiske samfunn i Norge.

Urfolksmetodologi har vore eit leiande prinsipp gjennom heile studien. Denne metodologien har vokse fram som ein reaksjon på at kunnskapsproduksjon ofte er fundamentert i eit vestlig verdsbilde, ideologi og ideal. Som eit kontraperspektiv, tilbyr urfolksmetodologi verktøy for å skrive forteljingar og produsere kunnskap som er fundamentert i urfolkssamfunn sine verdsbilde, ideologiar og ideal (Smith, 2012). Urfolksmetodologien stiller krav til lokal forankring av forsking for å sikre at forskinga blir relevant og nyttig for dei den gjeld (Denzin, Lincoln, \& Smith, 2008; Jordan, 2014). For å sikre forskinga sin relevans, må forskar respektere den samiske kulturelle integritet. I tillegg må kunnskapsproduksjonen skje i 
gjensidige relasjonar mellom forskar og forskingsfelt, der samfunnsmedlemmar frå dei samiske samfunna har ei aktiv og deltakande rolle (Kirkness \& Barnhardt, 1991). I praksis har vi gjort dette ved å vere i dialog med lokalsamfunn både gjennom utvikling av studien, $\mathrm{i}$ produksjon av data og ved analyse av funn.

Sidan denne studien vart initiert av RESAK, og utviklinga av tema for studien er gjort $\mathrm{i}$ samarbeid med dei, har dei vore ein samtalepartnar gjennom heile studien. For å sikre dialog med lokalsamfunn i produksjon av data forma vi fokusgruppe intervju som mini-seminar. Desse seminara bestod av a) presentasjon frå forskerar-teamet, og b) fokusgruppe intervju. I presentasjonen presenterte vi formålet med forskingsprosjektet, familierådsmodellen, sosialt arbeid i samiske samfunn for sosialarbeidarar i Montana, og sosialt arbeid i native amerikanske samfunn for sosialarbeidarar i Norge. Vidare vart analysar og funn så langt i forskingsprosessen presentert. Innspel frå deltakarane var heile vegen med å styre vårt blikk for dei komande intervjua. Lokalsamfunn er også involvert i analyse av funn. I gi-tilbake seminar har vi presentert tidlege funn frå prosjektet til både informantar og andre i lokalsamfunnet. Desse seminara fungerte som ein kvalitetssikring av analysen. Vi tok opp vår forståing og diskuterte dette med kompetente menneske i lokalsamfunnet. For meir om forskingsprosessen les Nygård (2018) og Nygård \& Saus (2016).

\section{Fokusgruppeintervju}

Vi har vore interessert i å utforske sosialarbeidarar i samiske samfunn sine erfaringar, idear og meiningar om familieråd og familieinvolvering. For å studere dette finn vi fokusgruppe intervju som ein egna metode. I eit fokusgruppe intervju kan ein utforske dei idear, språk og konstruksjonar som er delt mellom menneske i ein kontekst (Wilkinson, 1998). Intervjua følg eit semistrukturert design. Vi har ein intervjuguide med tema og spørsmål vi vil belyse, men følg flyten i intervjua og stiller oppfølgingsspørsmål til dei tema informantane bringer inn. 


\section{Deltakarar}

Deltakarar i studien er sosialarbeidarar i velferdstenester i samiske samfunn.

Dei som har delteke i studien er sosialarbeidarar i barnevernet, barnevernsleiarar, sosialarbeidarar hos NAV, eller sosialarbeidarar på RESAK. Deltakarane er samla i fokusgrupper saman med sine kollegaer. Vi har vore i kommunar i dei tre nordlige fylka, Nordland, Troms og Finnmark. Vi har gjennomført seks fokusgruppe intervju, med til saman seksten deltakarar. Fem av deltakarane er menn, og elleve er kvinner. Kommunane vi har besøkt er små, og i nokre intervju har det derfor vore berre to deltakarar. Dette er ei metodisk utfordring sidan vi i ei fokusgruppe ønskjer ein gruppediskusjon. Vi har likevel følgt fokusgruppe intervju design og lagt opp til refleksjon og samtale mellom deltakarane i intervjuet.

I denne analysen skil vi ikkje på deltakarane sin etniske identitet fordi etnisitet ikkje er ein gjensidig ute lukkande kategori i nordnorske samfunn (Oskal, 2003; Selle, Semb, Stømsnes, \& Nordø, 2015). Folk vil kunne identifisere seg ulikt i ulike kontekstar. Nokon vil identifisere seg som samisk i ein kontekst og norsk i ein annan kontekst. Eit eksempel frå denne studien, er eit intervju der det blir hevda at 'ingen av oss er samisk'. Den eine informanten fortel på eit anna tidspunkt at mor henna snakka samisk (Nygård, Saus, \& Nicolai, 2018). Dette er berre eit eksempel på at kategorien samisk versus ikkje-samisk nokon gangar er flytande eller missledande

Dei ansatte på RESAK er sosialarbeidarar med lang erfaring frå sosialt arbeid i samiske samfunn. Derfor har dei, på tross av at dei er samarbeidspartnar, også deltatt som informantar i studien. Dei er i intervjua anonymisert på lik linje med andre informantar. 


\section{Tema for intervju}

Utgangspunktet for studien var eit ønske om meir kunnskap om familieråd for bruk i samiske samfunn. Dei som deltar i intervjua har ulik mengde erfaring med familieråd. To av tenestene har gjennomført eit familieråd. Ei av tenestene har hatt to familieråd. Ei av tenestene har to gjennomførte familieråd, i tillegg har dei hatt eit familieråd som vart avslutta før sjølve møtet. Ei av teneste har ingen erfaring med familieråd.

Alle sosialarbeidarane vi intervjuar kjenner til familierådsmodellen i teorien, og dei er målgruppe for den ønska implementeringa av familieråd i samiske samfunn. Den erfaringa dei har med å teste ut modellen er for nokon grunna i eigen motivasjon, for andre grunnar den i etterspørsel og oppfordring frå Bufetat. Her er motivasjonen for å bruke modellen varierande. Nokon ser modellen som egna og ønska. Andre oppfattar implementering av modellen som styrt og pålagt frå øvrigheita. Kva haldning ein har til modellen vil vere under påverknad av kva erfaring ein har både med implementering og med gjennomføring av familieråd.

Sjølv om sosialarbeidarane har lite erfaring med familierådsmodellen, har dei lang erfaring med å involvere familiar i sitt arbeid. I Nygård et al. (2018) beskriv vi korleis sosialarbeidarane ser involvering av familie som ein viktig del av kulturell tilpassing av sosialt arbeid til den samiske konteksten. Alle tenestene involvera familie og lokalsamfunn i sitt arbeid. Tenestene opplever at dei i større grad enn andre delar av tenesteapparatet inkludera og involvera familie i sin praksis. Korleis familie blir involvert variera derimot frå teneste til teneste. I intervjua har sosialarbeidarane blitt spurt om å fortelje om sin lokale kontekst, om kva erfaringar dei har med familieråd spesielt og familie involvering generelt. Dei blir spurt om korleis dei ser familieråd og familieinvolvering som kulturelt relevant for sosialt arbeid i eit samisk lokalsamfunn. 


\section{Analyse}

Gjennom intervju får vi ikkje vite kva deltakarane faktisk gjer i sin praksis. Det vi får vite noko om er kva dei forsøker å gjere (Boine, 2012; Boine \& Saus, 2012). For å få fram deltakerane sine refleksjonar og vurderingar, har vi valt analyse av meiningsinnhaldet som analysestrategi (Berg, 2012). I desse intervjua får vi tilgang til korleis sosialarbeidarane i sine arbeidsfellesskap snakkar om god og dårlig praksis for kulturelt relevant sosialt arbeid. Vi har identifisert tema i intervjua basert på teoretiske hovudprinsipp frå familierådsmodellen. På denne måten kan vi drøfte sosialarbeidarane sine erfaringar og idear frå samisk sosialt arbeid opp mot det teoretiske rammeverket for familieråd. Vi kan med dette seie noko om tilpassinga av familieråd til ein samisk kontekst.

Studien er meldt inn til NSD og har følgt forskingsetiske reglar om ivaretaking av den enkelte deltakar, samt sikring av forskingsdata. I tillegg til etiske omsyn tematisert og formalisert av norsk forskingsadministrasjon, har vi følgt forskingsetiske omsyn formulert innanfor urfolksmetodologi. I denne studien har vi inkludert representantar frå lokalsamfunn i planlegging, godkjenning og gjennomføring av studien. Vidare har vi hatt dialog om tidlige funn til dei som har deltatt i studien, samt andre relevante representantar frå samfunna vi har forska $\mathrm{i}$.

\section{Resultat}

I intervju med sosialarbeidarar i samiske samfunn blir fire av familierådsmodellen sine hjørnesteinar tematisert. Desse er 1) familieinvolvering, 2) drøfting og problemløysing i familien, 3) barnet si deltaking, 4) koordinator. Den siste hjørnesteinen, familien sin handlingsplan, er sjeldan tema i desse intervjua. Vi har endrar på rekkefølgja for den klassiske inndelinga av familierådet sine hjørnesteinar, for ein logisk oppbygging i denne artikkel. 


\section{Familieinvolvering}

I samtalar med sosialarbeidarar i samiske samfunn vi finn ei forhandling og ein diskusjon om kva rolle den utvida familie har i samiske samfunn i dag. Denne forhandlinga tar stad både internt mellom sosialarbeidarar i dei enkelte intervjua, og i materialet i sin heilskap mellom dei ulike intervjua. I nokre intervju blir familien si rolle i samiske samfunn artikulert tydelig som ein resurs som kan re-vitaliserast. I andre er dei meir usikre på kva rolle den samiske familien har i dag.

Sosialarbeidarane beskriv korleis brukarane dei jobbar med bevegar seg mellom 'det samiske' og 'det norske', samt det tradisjonelle og det moderne. I denne spenninga, erfara sosialarbeidarane at det kan oppstå ulike forventningar om kva familien skal vere innanfor samisk-norske familiar i dag. Sosialarbeidarane fortel både om familiar som stiller opp, og familiar som ikkje stiller opp, når familiemedlemmar har vanskar. Dei fortel at familiemedlemmar kan ha ulike forventingar om korleis familien skal fungere og kva roller ein skal ha i forhold til kvarandre.

I eit intervju blir ulike forventningar til familien si rolle beskrive som følgjande:

1: Sånn som en bestemor i en familie sa det;

'Dem vil jo ikke ha min hjelp. Jeg prøver å støtte dem, men dem avviser meg. Noen ganger så åpner de kanskje ikke døra en gang. Men jeg gir ikke opp, fordi det skal ikke ryktes om at jeg har gitt opp. Det skal man jo ikke gjøre. Man skal støtte og gi råd og veiledning til den yngre generasjon. Om hva som er riktig, og hva man burde gjøre og ikke gjøre, i vår familie har vi alltid gjort sånn og sånn. Men dem avviser meg, men jeg gir ikke opp. Jeg skal igjennom muren’ (intervju L).

Denne bestemora prøva å stille opp for den yngre familien, men den yngre familien ønska ikkje den hjelpa ho tilbyr. I denne familien er der ulike forventingar mellom den eldre og yngre generasjonen om kva ein familie skal vere. Når bestemor er redd for kva rykte ho skal få dersom ho gir opp å følge rolla som ein vegleiar og støtte person, seier det noko om forventningar i lokalsamfunnet om kva ein familie skal vere. Bestemor bær på ei forventing 
om at det er henna oppgåve å vere ein rådgivar og støtte.

I følgje sosialarbeidarane i intervjuet sitert over kan dei ulike forventningane til kva rolle ein har overfor kvarandre som storfamilie eller kjernefamilie kunne skape konfliktar eller dilemma innanfor familien. Ein sosialarbeidar viser til familieråd som ein mulig arena for å snakke om desse ulike oppfatningane og skape felles forståing. Ho ser familieråd som ein arena for å avklare forventningar om relasjonar og roller innanfor familien.

I eit anna intervju reflektera sosialarbeidarane over korleis fråværet av storfamilie for nokon kan opplevast som eit nederlag eller ein skam.

K3: Kanskje det føles som et nederlag. En alene mor, en alene far, eller et foreldrepar som ønsker å klare seg sjøl. Og det er et nederlag å skulle begynne å trekke inn familien. Det som egentlig var helt naturlig når man bare tenker tilbake til begynnelsen av 1900-tallet, de som bodde på store gårder. Der bestemor og tanter bodde rom i rom bortover, ikke sant

Intervjuer: Ja.

K3: Og så har det forsvunnet. Vi har flytta fra hverandre, og så skal man begynne å hjelpe hverandre igjen.

Intervjuer: Ja.

K3: $\quad$ Det er litt

Intervjuer: Litt uvant.

K3: Ja. Da var det naturlig. Nå skal mor i fjøset, og hun setter ungen i fanget på bestemora, og så går hun. Og så skal du nå plutselig gjøre det samme, men det er satt i et system (Intervju Q).

Fortellingane over fortel om ein kultur i transformasjon, og at dette verkar inn på korleis familiar identifisera seg med samisk kultur og identitet i dag. Vi tolkar dette som at endring i samisk kultur kan føre til at ulike familiemedlemmar har ulike forventningar til fellesskapet i storfamilien.

\section{Drøfting og problemløysing i familien}

Den andre hjørnesteinen i familieråd er familien si eigentid for drøfting og problemløysing. I

fleire av intervjua blir den samiske kommunikasjonsforma beskrive som indirekte. Ved denne type kommunikasjon forklarar sosialarbeidarane at ein må kjenne til kulturen for å forstå det 
som blir sagt mellom linjene. Nokon av dei samiske familiane blir også beskrive av

sosialarbeidarane som lukka, desse familiane held problem innanfor familien. Ein av

sosialarbeidarane utrykker bekymring for korleis det lukka og det stillteiande passar inn i ein

familierådsmodell:

I2: Det har jo vært noen studier som omtaler at samiske familier er opptatte av slekt og storfamilie, men så er det jo også at det snakkes lite om problemer og at det er lukket. Og at det er forenelig med familieråd når du skal tromme sammen og snakke om det som er vanskelig, den får jeg ikke helt til å stemme. Hva vet en om mulighetene for å få det til? For sånn, vi har jo ikke prøvd ordentlig familieråd, selv om vi har hatt opplæring. Men noen familier sier at nei, vi vil ikke trekke inn slekta. Men det får du selvfølgelig i både norske familier og samiske familier. Men hva som er spesielt og ikke spesielt med samiske familier. Akkurat det der med å ikke snakke om det som er vanskelig, og ikke snakke i slekta selv om en vet at han faren i det huset drikker mye alkohol så sies ikke det mye høyt, og tas ikke fatt i og sies kanskje ikke til den det gjelder, og en tier, en ser på det men tier. Og hvordan få det opp i et familieråd, og få jobbet med det, det er ikke enkelt [...]. For det er jo uvant, og det er ikke noe mer naturlig for samiske familier å sitte i stormøter og snakke om det som er vanskelig, kanskje tvert imot, i forhold til en taushet (Intervju O).

Sosialarbeidaren reflektera her rund utfordringar med det å ha 'samtalen om det vanskelige' i sentrum, i ein kultur der det vanskelige ikkje blir snakka om.

I eit intervju hos ei anna teneste framhevar sosialarbeidarane viktigheita av å tematisere og sette ord på det som ikkje blir snakka om.

I1: (...) men vi hadde en diskusjon i forkant av den første saken. Det var om skulle vi kalle det for fars psykiske problemer eller ikke, husker dere det? For jeg synes man skal kalle det for psykiske problemer, og jeg tror du sa at du ikke syntes det. Og jeg tenker at vi har tatt lærdom av det. At du skal kalle en spade for en spade. Fordi gutten så jo da far gikk inn i en dyp depresjon, lukka alle gardinene, døra, forsvant. Og da har barn en tendens til å tenke "har jeg gjort det der? Er det jeg som har sagt noe? Har jeg fornærmet pappa?”. Og så er han faktisk bare kjempesyk. Og det var ingen som reagerte på at det ble kalt for det, heller ikke far. Så det er også en lærdom. Er det rus i familien, så skal man også kalle det for rusproblemer (Intervju N).

Sosialarbeidarane reflektera over det å tematisere tabu i familien. Dei seier det er viktig å sette ord på vanskelige tema og utfordringar som familien står i. 


\section{Barnet si deltaking}

Den tredje hjørnesteinen frå familieråd er barnet si deltaking. Vi har ikkje spurt dirrekte etter barnet si rolle i familierådet eller i familieinvolvering. Likevel blir barnet snakka om i fleire av intervjua.

I eit intervju er det ein sosialarbeidar som artikulerer viktigheita av å sjå barnet som ein sjølvstendig aktør. Ho snakkar om at barneperspektivet i familieråd passar godt i forhold til samisk kultur. Ho seier det slik:

3: Når det gjelder barneperspektivet, eller barnesynet, det synes jeg også passer veldig godt. Intervjuer: kan ikke du si litt mer om det?

3: ja, for eksempel det med at barnet er aktør, jeg tenker det der å ha aktørperspektivet på barnet. Intervjuer: $\mathrm{mm}$

3: det synes jeg passer godt. Sånn som han her som lærte seg å kjøre scooter fra han var to år. Å være aktør, det skaper masse gode løsninger på situasjonen. Han kommer med forslag og kan masse og har

1: og det blir verdsatt, altså hans mestring blir verdsatt

3: ja, blir verdsatt og det fungerte jo, han fikk jo slutt på det med plageåndene gjennom sine fremgangsmåter, så det virka jo. Og det at barnet, han har vert aktør og han mestrer. Og modellen her legger bedre til rette for at barnet får den muligheten. Så barnet lærer seg jo å bli mestrende aktører fra de er små. Og det blir også verdsatt i kulturen. At barnet lærer seg å mestre nye arbeidsoppgaver og nye situasjoner. Jeg synes det synet på barn og det her med å tilrettelegg bedre for det barneperspektivet, det barnesynet. At barnet ikke er passivt (Intervju L).

I eit anna intervju blir det snakka om korleis barnet sjølv tok initiativ og snakka med sine slektningar i forkant av eit familieråd.

K: med en gang de fikk høre at nå skulle det komme et eller annet, så var de i gang med å jobbe fram de tingene som skulle fram

I1: og gutten selv var veldig aktiv

$\mathrm{K}$ : veldig aktiv

Intervjuer: hvordan da? hvordan var gutten aktiv?

K: han gikk på besøk til faddere og tanter og onkler og..

I1: og ordnet opp, rett og slett (Intervju N). 
Barnet si deltaking vart i dette intervjuet snakka om som viktig for at prosessen rundt familierådet vart god. I følgje sosialarbeidarane fekk guten gjennoppretta relasjonar og kontakt med sin familie, slik at familien kunne hjelpe og støtte han.

I intervjua snakkar sosialarbeidarane om at eit av måla med familieråd er å finne løysingar for korleis barnet kan oppretthalde eller skape tilknyting til lokalsamfunn, kultur og språk.

Sosialarbeidarane er opptatt av å finne løysingar nært i lokalsamfunnet. Dersom eit barn skal plasserast utanfor heimen ser dei det som viktig at barnet ikkje må flytte langt vekk frå sitt lokale miljø og kultur. I eit intervju blir det fortalt om eit barn der den viktigaste kjelda for å lære samisk er kontakt med bestemor. For eit anna barn er kontakt med far sin familie den viktigaste kjelda for å lære praktiske ferdigheiter på reingjerdet. For eit tredje barn ønskjer familien at barnet skal lære seg språk og praktiske kulturelle ferdigheiter, men barnet sjølv har ikkje denne interessa. Desse barna har ulik tilknyting, og ulike behov for tilknyting til sin kultur.

\section{Koordinator}

Den fjerde hjørnesteinen i familieråd er tilrettelegging frå ein uavhengig koordinator. I fleire av intervjua blir koordinator sin kulturkunnskap og lokalkunnskap etterspurt. I eit intervju seier sosialarbeidarane at det kan vere ei utfordring for familiane at det skal komme eit nytt, framand menneske inn i familien for å koordinere. I eit anna intervju fortel sosialarbeidarane korleis dei vegrar seg for å overlate familien til ein person som kjem utanfrå og ikkje kjenner lokalsamfunnet.

I1: Så den lokalkunnskapen kan man jo ikke forvente inn hos en sånn koordinator. Og det så vi jo kanskje på det ene familierådet vi hadde, at det kunne kanskje vært gjort litt annerledes, hvis den koordinatoren hadde hatt lokalkunnskap. I familierådet skal ikkje vi inn, det skal være disse utenfra, vi skal ikke inn dit, og da skal vi heller ikke gi den tause kunnskapen, tenker jeg. Da må den løses på annet vis. Da blir det systemet, systematikken/metoden, på en måte, som er nøkkelen (Intervju P). 
I eit tredje intervju legg sosialarbeidarane vekt på at koordinator må kjenne dei kulturelle normene i samisk kommunikasjon, slik at dei fangar opp også det som ikkje blir satt ord på.

I1: Også tenker jeg når de tier og sånt, at man, da er det ofte noe som er galt der. Ikke sant, hvis du spør har du snakket om det? 'Nei, ja, ja vi snakker jo litt', og du får ikke noen gode svar, så ligger det der enda. Det er helt sikkert. Det er akkurat det der, hvordan få tak i det som ikke blir sagt. Det kan nok være at disse metodene ikke tar høyde nok for, at hvis ikke de som jobber med de metodene er obs på akkurat de tingene der, så vil det gå hus forbi (Intervju O).

I denne delen av intervjuet snakkar sosialarbeidarane om at dei som jobbar etter manualbaserte metodar må kjenne til den lokale konteksten dei jobbar innanfor. Intervjuar spør om dette også gjeld for koordinator i familierådet. Sosialarbeidarane svarar at dette også gjeld koordinator i familierådet. Koordinator skal legge til rette for familierådet sin prosess, og snakke med familiemedlemmar. Dei må kjenne til kommunikasjonsformene i den kulturelle konteksten dei jobbar i. Den tenesta som ser ut til å ha dei mest positive erfaringane med familieråd har ein koordinator som har tilknyting til lokalsamfunnet.

\section{Diskusjon}

I det følgjande vil vi drøfte korleis familierådsmodellen kan tilpassast samiske kontekstar. Vi ser spesielt på dei fire hjørnesteinane; 1) familieinvolvering, 2) familien si eigentid for drøfting og problemløysing, 3) barnet si deltaking, 4) uavhengig koordinator.

\section{Ein modell for familieinvolvering}

Den samiske storfamilien blir framheva som ein sentral del av samisk kultur (Henriksen, 2004a; Juuso, 2000). I denne studien finn vi ein pågåande diskusjon om familien si rolle i samiske samfunn i dag. Sosialarbeidarane snakkar om familiar som bevegar seg mellom 'det samiske' og 'det norske'. Våre analysar viser at sosialarbeidarane også bevegar seg i dette spennet.

Bevegelsar i kultur og endring i familieband kan kjennast igjen også frå norsk kultur.

Kulturelle mønster endrar seg mellom generasjonar. Transformasjon av samisk kultur har 
likevel ein ekstra dimensjon. I tillegg til å vere eit resultat av samfunnsprosessar som modernisering og urbanisering er den eit resultat av ein systematisk fornorsking av samisk kultur.

Både Saus (2008) og Kemi (2000) viser korleis endringane i samisk kultur kan føre til skam hos enkeltmenneske. Når familien ikkje stiller opp slik det blir forventa utifrå rådande idear om samisk kultur tolkar den enkelte det som at han eller ho ikkje er 'samisk nok' (Kemi, 2000) eller at det er ein sjølve som ikkje klarar å gi familien ei rolle (Saus, 2008). I samiske familiar i dag kan ulike familiemedlemmar ha ulike forventingar til kva rolle ein skal ha i forhold til kvarandre. Dette kan skape konfliktar i familien.

Vi meina det er grunn til å reflektere over korleis det vil vere for menneske som bær på ein skam over tap av familieband å møte eit tenesteapparat som forventar deltaking frå familie. I slike møte mellom tenesteapparat og enkeltmenneske kan den enkelte sin følelse av å ikkje få til å skape familierelasjonar bli forsterka. Når ein implementerar ein modell som tar utgangspunkt i eit storfamilie system der fellesskapet stiller opp, i eit samfunn der storfamilie systemet er i endring, må modellen sitt teoretiske rammeverket spegle denne endringa. Eit tilpassa teoretiske rammeverk for familieråd reflektera spenninga i samiske familieverdiar.

\section{Ein modell som legg til rette for drøfting og problemløysing}

Sosialarbeidarane tar opp tema 'indirekte kommunikasjonsformer’ og 'det å holde problem innanfor familie’ når dei snakka om modellen sitt potensiale for å legge til rette for problem løysing.

Der er ei forventning frå tenesteapparatet om at samiske familiar ikkje snakkar om det som er vanskelig (Kemi, 2000; Øverli et al., 2017). Denne tendensen finn vi også i vårt materiale. Dagsvold (2019) poengtera viktigheita av å ikkje la statiske kultur karakteristika styre 
hjelpetilbodet til samisk befolkning. Forventningar om at samiske familiar ikkje snakkar om vanskelige tema kan skape ein situasjon der samiske brukarar får mindre hjelp enn andre delar av befolkninga (Blix \& Hamran, 2017; Øverli et al., 2017). Kemi (2000) og Øverli et al. (2017) tematiserer viktigheita av at tenesteapparatet tør å sette ord på tabubelagte tema.

Å ta omsyn til den samiske indirekte kommunikasjonsforma betyr ikkje nødvendigvis å la vere å snakke om det som er vanskelig. Boine (2010) viser korleis det er viktig å forstå den samiske kommunikasjonsforma for å kunne tilpasse møtet med den samiske brukar på ein kulturelt god måte. Familieråd kan vere eit verktøy og ein arena for å sette ord på utfordringar familien står i. Eit teoretisk rammeverk for familieråd i samiske samfunn bør derfor tematisere indirekte kommunikasjon som ein mulig kommunikasjonsform å vere merksam på.

Når sosialarbeidarar i samiske samfunn opplever at nokon familiar er lukka og ønskjer å halde familieproblem innanfor familien, må vi sjå dette i relasjon til velferdsstaten si undertrykkande rolle gjennom fornorskingstida. Fleire studiar viser at der er eit opplevd skilje mellom 'samane' og ‘dei norske', eller mellom 'den samiske brukar' og 'den norske velferdstenesta' både frå den samiske bruker og frå representanten frå velferdsstaten (Blix \& Hamran, 2017; Dyregrov, Berntsen, \& Silviken, 2014). For ein familie som opplever ein distanse til velferdssystemet vil det å løyse problem innanfor familien kunne opplevast som ei betre løysing enn å involvere ein offentlig instans. Vi etterspør eit teoretisk rammeverk for familieråd som gjennoppretting av tillit mellom familien og velferdstenesta.

\section{Ein modell for barnet si deltaking}

Moderne samfunn blir ofte karakterisert som individualistisk, der retten til autonomi og sjølvstendigheit blir verdsatt (Lay et al., 1998; Oyserman, Coon, \& Kemmelmeier, 2002; Østberg, 1999). Innanfor rettsstaten og sosialt arbeid blir ofte barnets rett til autonomi og 
sjølvstendigheit framheva til fordel for retten til tilknyting til signifikante andre (Brooks \& Ronen, 2006). Innanfor velferdsstaten er der eit aukande fokus på barnets rett til å bli høyrt (Hennum, 2010). Som ein konsekvens av dette, har den norske teoriutviklinga av familieråd satt prinsippet om barnet sin rett til deltaking høgt (Strandbu, 2007).

I samisk kultur er eit viktig element i barneoppdraginga å gjere barnet sjølvstendig i seg sjølv og saman med andre (Boine, 2005). I praksis vil fokuset på barnet si deltaking i familieråd kanskje ikkje vere så ulikt i det norske og det samiske familierådet. Men dei teoretiske og ideologiske grunnprinsippa bak barnet si deltaking vil kunne skilje seg frå kvarandre. Dette bør eit teoretisk rammeverk for familieråd til bruk i samiske samfunn fange opp. Ein familierådsmodell til bruk i samiske samfunn bør ha eit teoretisk rammeverk som inkludera synet på barn og barndom i samisk kultur.

I tillegg til retten til autonomi har barn etter barnekonvensjonen rett til tilknyting til signifikante andre (Brooks \& Ronen, 2006). Etter ILO konvensjonen har barnet også rett til ivaretaking av sin kultur (International Labour Organization (ILO), 1980). Ideologien bak barnet si deltaking og autonomi spring ut i frå ein individualistisk ide om barnet sin rett til aktørskap. Barnet sin rett til å delta kan også forsterke barnet sin rett til tilknyting.

I intervjua referera sosialarbeidarane til barn med ulike behov for korleis deira tilknyting til signifikante andre og til kultur kan bli ivaretatt. Det er ein kompleksitet i korleis best sikre det enkelte samiske barn si tilknyting til samisk kultur og språk. Å vere samisk betyr ikkje det same i alle lokalsamfunn eller i alle familiar. Sosialarbeidarane snakkar om at der er ulike samiske utrykk og identitetar både innanfor ein familie og mellom ulike lokalsamfunn. Å gi barnet kontinuitet i kulturell tilknyting vil derfor vere komplekst. Denne kompleksiteten må fangast opp av sosialt arbeid og metodar innanfor sosialt arbeid. Dei ulike behova og 
tilgangane til kulturell tilknyting krev ein kunnskap og ein fleksibilitet frå sosialarbeidar i møte med barn og familie. Ivaretakinga må tilpassast det enkelte barn. Barnet si deltaking vil kunne vere eit steg mot å finne dei formene for tilknyting som passar det enkelte barn.

\section{Ein modell der uavhengig koordinator hjelp familien med tilrettelegging}

I denne studien blir koordinator sin kulturkunnskap og lokalkunnskap løfta fram. Nygård (2018) tematisera korleis sosialarbeidarar i samiske samfunn plassera lokalkunnskap i sentrum når dei skal beskrive kulturell tilpassing av sosialt arbeid. Kunnskap om kultur, historie og lokale forhold blir framheva som sentralt for kulturelt tilpassa sosialt arbeid i urfolkssamfunn verda over (Archibald, 2006; Weaver, 2004). Innafor samisk barnevern konkretisera Saus (2008) denne kunnskapen med omgrepet kontekstuelt barnevern.

For å kunne fange opp dei prosessane som skjer i familien og i lokalsamfunnet, er kunnskap om den lokale dynamikken i lokalsamfunnet viktig. Ein koordinator i familieråd skal legge til rette for den praktiske gjennomføringa av familierådet. Koordinator skal kommunisere mellom familien og sosialarbeidar. Koordinator skal også legge til rette for dialog mellom familiemedlemmar. Når ein koordinator skal inn og jobbe i ein familie vil det vere viktig at også koordinator har ein profesjonell nærleik til familien og lokalsamfunnet.

I denne artikkel tematisera vi koordinator si rolle sist, sjølv om dette ikkje er den tradisjonelle inndelinga for familierådets hjørnesteinar. Dette fordi dei teoretiske byggeklossane familieinvolvering, problemløysing i familien, og barnets rolle i familieråd alle inngår i koordinator sin kunnskapspakke. 


\section{Konklusjon}

Familierådsmodellen krev ein tilpassing til samiske forhold før implementering i samiske samfunn. Samfunn, familiar og enkelt individ har ulike samiske utrykk og tilknyting. Ein metodetilpassing må ta høgde for ulike måtar å identifisere seg som samisk i dag. Eit teoretisk fundament for ein samisk familierådsmodell ser den samiske storfamilien i spennet mellom 'det samiske’ og 'det norske', og tematisera korleis fornorsking kan påverke samspelet i ein familie, samt mellom familiar og hjelpeapparatet. Det teoretisk rammeverk for familieråd drøftar gjennoppretting av tillit innanfor familien, og mellom familie og velferdstenesta. For lokal tilpassing må koordinator, i tillegg til sosialarbeider, ha kunnskap om lokal kontekst.

\section{Litteratur}

Archibald, L. (2006). Decolonization and Healing: Indigenous Experiences in the United States, New Zealand, Australia and Greenland. The Aboriginal Healing Foundation Research Series. Ottawa, Canada: Aboriginal Healing Foundation.

Balto, A. (1997). Samisk barneoppdragelse i endring. Oslo, Norge: Gyldendal.

Ban, P. (2005). Aboriginal Child Placement Principle and Family Group Conferences. Australian Social Work, 58, 384-394. doi:10.1111/j.1447-0748.2005.00234.x

Berg, B. L. (2012). Qualitative research methods for the social sciences (8th ed.). Boston: Pearson.

Bjørklund, I. (1985). Fjordfolket i Kvoenangen: fra samisk samfunn til norsk utkant 15501980. Tromsø: Universitetsforlaget.

Blix, B. H., \& Hamran, T. (2017). "They take care of their own": healthcare professionals' constructions of Sami persons with dementia and their families' reluctance to seek and accept help through attributions to multiple contexts. Int J Circumpolar Health, 76(1), 1328962. doi:10.1080/22423982.2017.1328962

Boine, E. M. (2005). Fra far til sønn: kjønnsperspektiv og sosial kompetanse $i$ samisk sammenheng. (MA), E.M. Boine, Trondheim, Norge.

Boine, E. M. (2010). Kulturorientert praksis - en veileder Tromsø, Norge: Barnevernets utviklingssenter for Nord-Norge. UiT - Norges Arktiske Univeristet.

Boine, E. M. (2012). Minoritetskultur i barneverninstitusjon. In R. G. Gjærum, M. Saus, \& A. Strandbu (Eds.), Barns inntrykk, uttrykk og avtrykk: om kreativitet og medbestemmelse (Vol. BUKS 56). Odense, Denmark: Syddansk universitetsforlag.

Boine, E. M., \& Saus, M. (2012). Saamelaisten isien Kasvatusstrategioita [Samiske fedrers oppdragelsesstrategier]. In A. Lauriala (Ed.), Koulu ja pohjoisen pojat [Gutter i skolen $i$ nord]. Rovaniemi, Finland: University of Lapland Lapin Yliopisto.

Bongo, B. A. (2012). "Samer snakker ikke om helse og sykdom": samisk forståelseshorisont og kommunikasjon om helse og sykdom: en kvalitativ undersøkelse i samisk kultur. (Doctor dissertation), Universitetet i Tromsø, Tromsø, Norge. 
Brooks, S. L., \& Ronen, Y. (2006). The notion of interdependence and its implications for child and family policy. Journal of Feminist Family Therapy, 17, 23-46. doi:10.1300/J086v17n03_02

Bufdir. (2013). (Samisk) Mitt familieråd - en film for barn, https://www.youtube.com/watch? $\mathrm{v}=\mathrm{qCnuGJFwBKw}$.

Connolly, M. (2009). Family group conferences in child welfare: the fit with restorative justice. Contemporary Justice Review, 12, 309-319. doi:10.1080/10282580903105822

Dagsvold, I. (2019). Cultural adaption of mental health services to the Sami. A qualitative study on the incorporation of Sami language and culture into mental health services. (Doctoral dissertation), UiT - The Arctic University of Norway, Tromsø, Norge.

Dagsvold, I., Møllersen, S., \& Stordahl, V. (2015). What can we talk about, in which language, in what way and with whom? Sami patients' experiences of language choice and cultural norms in mental health treatment. International Journal of Circumpolar Health, 74(1), 26952. doi:10.3402/ijch.v74.26952

Dankertsen, A. (2014). Samisk artikulasjon: melankoli, tap og forsoning $i$ en (nord)norsk hverdag. (Doctoral dissertation), Nordland University, Faculty of Social Sciences, Bodø, Norge.

Denzin, N. K., Lincoln, Y. S., \& Smith, L. T. (2008). Handbook of critical and indigenous methodologies. Los Angeles, California: Sage.

Drywater-Whitekiller, V. (2014). Family Group Conferencing: An Indigenous Practice Approach to Compliance With the Indian Child Welfare Act. Journal of Public Child Welfare, 8, 260-278. doi:10.1080/15548732.2014.907102

Dyregrov, K., Berntsen, G., \& Silviken, A. (2014). The need for and barriers to professional help: a qualitative study of the bereaved in Sámi areas. [http://www.suicidologyonline.com/articles.html ]. Suicidology Online Open access journal, 5, 47-58.

Eidheim, H. (1971). Aspects of the Lappish minority situation. Oslo: Universitetsforlaget.

Eidheim, H., \& Stordahl, V. (1998). Kulturmøte og terapi i Sápmi. Kárášjohka: Davvi girji.

Erke, R. (1986). Sosial organisasjon. In R. Erke \& A. Høgmo (Eds.), Identitet og livsutfoldelse. En artikkelsamling om flerfloklige samfunn med vekt på samenes situasjon(pp. 25-37). Tromsø, Norge: Universitetsforlaget.

Falck, S. (2009). Hva er det med familieråd? Samlerapport fra prosjektet: 'Nasjonal satsing for utprøving og evaluering av familieråd i Norge'. Oslo, Norge: Norsk institutt for forskning om oppvekst, velferd og aldring.

Gilbert, A. (2013). Community-Based Child Care in Ethiopia vs. the Individual Centered Model in the United States: A Closer Examination of Family Group Decision Making in Child Placement. Children's Legal Rights Journal, 33(2), 348-376.

Gray, M., Coates, J., Yellow Bird, M., \& Hetherington, T. (2016). Decolonizing Social Work (New edition ed.). Farnham, England: Ashgate Publishing Company.

Grenersen, G. (1995). Kulturell gjenreisning $i$ et markesamisk kjerneområde: $i$ spenningsfeltet mellom forskning, politikk og folkelig selvforståelse. (Doctoral dissertation), Universitetet i Tromsø, Tromsø, Norge.

Hanssen, E. S. S. (2004). Samiske barn og unge i barnevernet - betydning av tilhørighet. In I. M. Tronvoll, A. Moe, \& J. E. Henriksen (Eds.), Hjelp i kontekst (pp. 90-102). Otta, Norge: Idut.

Havnen, K. J. S., \& Christiansen, Ø. (2014). Kunnskapsstatus om familieråd. Erfaringer og effekter. Bergen: Uni Research.

Hennum, N. (2010). Mot en standardisering av voksenhet? Barn som redskap i statens disiplinering av voksne. Sosiologi i dag, 40(1-2), 57-75.

Henriksen, J. E. (2004a). Den samiske storfamilien i et nettverksperspektiv. In I. M. Tronvoll, A. Moe, \& J. E. Henriksen (Eds.), Hjelp i kontekst (pp. 40-59). Otta, Norge: Idut. 
Henriksen, J. E. (2004b). Det kultur-kontekstuelle nettverksdiagrammet som redskap i familieråd og nettverksarbeid. In I. M. Tronvoll, A. Moe, \& J. E. Henriksen (Eds.), Hjelp i kontekst (pp. 60-72). Otta, Norge: Idut.

Hill, L. F. (2005). Family Group Conferencing: An Alternative Approach to the Placement of Alaska Native Children under the Indian Child Welfare Act. Alaskan Law Review, 22, 89-112.

Holkup, P. A., Salois, E. M., Tripp-Reimer, T., \& Weinert, C. (2007). Drawing on Wisdom From the Past: An Elder Abuse Intervention With Tribal Communities. Gerontologist, 47, 248-254. doi:10.1093/geront/47.2.248

Horverak, S. (2009). Familieråd og nettverksråd. Oslo, Norge: Universitetsforlaget.

International Labour Organization (ILO). (1980). Indigenous and Tribal Peoples Convention (NO. 169).

Johansen, S. B. (2004). "...har alltid levd i fred og fordragelighet med hverandre." Problemer i kjølvannet av fornorskningen. In H. Eidheim \& V. Stordahl (Eds.), Kulturmøte og terapi i Sápmi (2nd ed., pp. 83-106). Finland: Davvi Girji.

Jordan, S. (2014). Indigenous Research Methods. The SAGE Encyclopedia of Action Research. London: SAGE Publications

Juuso, J. (2000). Samiskhet under endring - Barns syn på etnisk identitet og slektsnettverk. (Master thesis), Norges Tenkniske Naturvitenskaplige Universitet, Trondheim, Norge.

Kemi, R. (2000). Barndom, nåtid og fremtid: voksne samer forteller om sin oppvekst i en rusmisbruker familie. (Master thesis), Trondheim; Norge.

Kirkness, V. J., \& Barnhardt, R. (1991). First Nations and higher education: The four R'sRespect, relevance, reciprocity, responsibility. Journal of American Indian Education, $1-15$.

Langås-Larsen, A., Salamonsen, A., Kristoffersen, A. E., Hamran, T., Evjen, B., \& Stub, T. (2018). "We own the illness": A qualitative study of networks in two communities with mixed ethnicity in Northern Norway. International Journal of Circumpolar Health, 77(1), 1438572. doi:10.1080/22423982.2018.1438572

Lay, C., Fairlie, P., Jackson, S., Ricci, T., Eisenberg, J., Sato, T., . . Melamud, A. (1998). Domain-Specific Allocentrism-Idiocentrism: A Measure of Family Connectedness. Journal of Cross-Cultural Psychology, 29(3), 434-460. doi:10.1177/0022022198293004

Love, C. (2000). Family Group Conferencing. Cultural Origins, Sharing and Appropriation A Maori Reflection. In G. Burford \& J. Hudson (Eds.), Family group conferencingNew directions in community-centred child \& family practice. New Jersey, New Jersey: Transaction Publishers.

Love, C. (2002). Mãori perspectives on collaboration and colonisation in contemporary Aotearoa/New Zealand child and family welfare policies and practices. Canada: Social work, Wilfred Laurier University.

Marcynyszyn, L. A., Bear, P. S., Geary, E., Conti, R., Pecora, P. J., Day, P. A., \& Wilson, S. T. (2012). Family Group Decision Making (FGDM) with Lakota Families in Two Tribal Communities: Tools to Facilitate FGDM Implementation and Evaluation. Child Welfare, 91, 113-134.

Maxwell, G. (2008). Crossing Cultural boundaries: Implementing Restorative Justice in International and Indigenous Contexts. In H. V. Miller (Ed.), Restorative Justice: from Theory to Practice (Vol. 11, pp. 81-95). Bingley, United Kingdom: Emerald Group Publishing Limited.

Meyer, J. F. (1998). History repeats itself: Restorative justice in Native American Communities. Journal of Contemporary Criminal Justice, 14(1), 42-57. doi:10.1177/1043986298014001004 
Meyer, J. F. (2002). "It is a gift from the creator to keep us in harmony:" original (vs. Alternative) dispute resolution on the navajo nation. International Journal of Public Administration, 25(11), 1379-1401. doi:10.1081/PAD-120013351

Minde, H. (2005). Assimilation of the Sami-implementation and consequences. Journal of Indigenous Peoples Rights, 3, 3-33.

Nergård, J.-I. (1992). Den vuxna barndomen: den psykotiske personen som vägvisare $i$ vår kultur. Ludvika: Dualis.

Nergård, J.-I. (1994). Det skjulte Nord-Norge. Oslo: Gyldendal.

Nergård, V. (2005). Slekt og rituelt slektskap i samiske samfunn: innspill til en psykodynamisk forståelse av sosialisering. (Doctoral dissertation), Det utdanningsvitenskapelige fakultet, Universitetet i Oslo Unipub, Oslo.

Nordisk Samekonferanse. (1980). Vi samer er et folk - en nasjon : samepolitisk program vedtatt på den XI. Nordiske samekonferanse. . Retrieved from Charta 79:

Nordland Politidistrikt. (2017). Overgrepene i Tysfjord. Nordland, Norge: Nordland Politidistrikt.

Nygård, R. H. (2018). Family and community involvement in indigenous social work: a comparative study. (Doctoral dissertation), UiT The Arctic University of Norway, Faculty of Health Sciences, Regional Center for Child and Youth Mental Health \& Child Welfare, Tromsø.

Nygård, R. H., \& Saus, M. (2016). Emphasizing indigenous communities in social work research ethics. International Social Work, 59(5), 666-678. doi:10.1177/0020872816646815

Nygård, R. H., \& Saus, M. (2019). Is Family Group Conferencing a culturally adequate method outside its origin in New Zealand? A meta-synthesis. Social Work and Social Sciences Review, 20, 78-108.

Nygård, R. H., Saus, M., \& Nicolai, S. S. (2018). Conceptualization of culture and ethnicity within social work in two indigenous communities. Journal of Comparative social Work, 13, 27-27.

Nystad, K., Spein, A. R., \& Ingstad, B. (2014). Community resilience factors among indigenous Sámi adolescents: A qualitative study in Northern Norway. Transcult Psychiatry, 51(5), 651-672. doi:10.1177/136346151453251

Oskal, N. (2003). Samisk offentlighet og demokrati på norsk. In B. Bjerkli \& P. Selle (Eds.), Samer, Makt og Demokrati. Sametinget og den nye samiske offentligheten (pp. 318337). Oslo, Norge: Gyldendal.

Oyserman, D., Coon, H. M., \& Kemmelmeier, M. (2002). Rethinking individualism and collectivism: evaluation of theoretical assumptions and meta-analyses. Psychol Bull, 128(1), 3-72. doi:10.1037/0033-2909.128.1.3

Pedersen, P., \& Nyseth, T. (2015). City-Saami. Same i byen eller bysame? Kárášjohka: Č́lliidLágádus.

Pennell, J., \& Anderson, G. (2005). Widening the Circle. The Practice and Evaluation of Family Group Conferencing with Children, Youths, and Their Families. Washington, D. C: NASW Press.

Pranis, K. (2015). Little Book of Circle Processes: A New/Old Approach To Peacemaking. New York: Good Books.

Sárgon, S. (2007). Konsekvenser av statens fornorskningspolitikk - med fokus på tapt skolegang under andre verdenskrig. (Spesialpedagogikk Master), Universitetet i Tromsø,.

Saus, M. (2008). Kontekstuelt barnevern. Barnevernet i det samiske landskap. (Doctoral dissertation), Barnevernets Utviklingssenter i Nord-Norge, Troms $\varnothing$, Norge. 
Saus, M., \& Boine, E. M. (2008). Kunnskapsstatus og Kunnskapsbehov - for barnevernet $i$ samiske områder (Vol. 2): Barnevernets Utviklingssenter i Nord-Norge.

Saus, M., Salamonsen, A., Douglas, M., Hansen, K. L., \& Thode, S. K. (2018). Utredning om barnevern for den samiske befolkningen, innvandrere og nasjonale minoriteter $i$ Norge. Kompetansehevende tiltak, kunnskapsmiljø og samiske barns scerlige rettigheter. RKBU Nord, UiT the Arctic University of Tromsø. Tromsø, Norge.

Selle, P., Semb, A. J., Stømsnes, K., \& Nordø, Å. D. (2015). Den samiske medborgeren. Oslo, Norway: Cappelen Damm Akademisk.

Sending, V. J., Strandbu, A., \& Thørnblad, R. (2015). RKBU Nord Rapport 2015: «Familieråd i fosterhjemsarbeid»Presentasjon av utvalg, datamateriale og prosedyrer for datainnsamlingen. Tromsø, Norway: RKBU Nord, UiT.

Sinclair, R. (2004). Aboriginal social work education in Canada: Decolonizing pedagogy for the seventh generation. First Peoples Child \& Family Review, 1(1), 49-62.

Slettebø, T. (2000). Empowerment som tilnærming i sosialt arbeid. Nordisk sosialt arbeid, 2(00), 75-85.

Smith, L. T. (2012). Decolonizing Methodologies. Research and indigenous peoples. London, United Kingdom: Zed Books.

SSB. (2019). Samisk Statistikk 2012. Retrieved from SSB, https://www.ssb.no/befolkning/artikler-og-publikasjoner/urbefolkningen-i-tall-samiskstatistikk:

Strandbu, A. (2007). Barns deltakelse og barneperspektivet i familierådsmodellen. (Doctoral dissertation), Universitetet i Tromsø, Tromsø, Norway.

The Maori Perspective Advisory Committee. (1998/2001). PUAO-TE-ATA-TU, The Report of the Ministeral Advisory Committee on a Maori Perspective for the Departement of Social Welfare. Wellington, New Zealand.

Tronvoll, I. M., Moe, A., \& Henriksen, J. E. (2004). Hjelp i kontekst: praksis, refleksjon og forskning. Indre Billefjord: Iðut.

Vars, L. S. (2017). Samene i Norge: Fra fornorskning til forsoning? In N. Brandal, C. A. Døving, \& I. T. Plesner (Eds.), Nasjonale minoriteter og urfolk i norsk politikk fra 1900 til 2016 (pp. 177-200). Oslo, Norge: Cappelen Damm Akademiske.

Weaver, H. N. (2004). The Elements of Cultural Competence. Journal of Ethnic \& Cultural Diversity in Social Work, 13(1), 19-35. doi:10.1300/J051v13n01_02

Wilhelmsen, K. S. (2010). Kulturelle elementer i kognitiv atferdsterapi: $\bar{b}$ ehandling av mørkeredsel hos en samisk gutt. In Anne Silviken og Vigdis Stordahl (Eds.), Samisk psykisk helsevern (pp. 86-106). Kárášjohka, Norge: ČálliidLágádus.

Wilkinson, S. (1998). Focus groups in health research: exploring the meanings of health and illness. J Health Psychol, 3(3), 329-348. doi:10.1177/135910539800300304

Zehr, H. (2002). The Little Book of Restorative Justice Intercourse, Pennsylvania: Good Books.

Østberg, D. (1999). Det moderne. Et essay om Vestens kultur 1740-2000 [Modernity. An essay on the culture of the West 1740-2000]. Gjøvik, Norway: Gyldendal Norsk Forlag.

Øverli, T., Bergman, S., \& Finstad, A.-K. (2017). «Om du tør å spørre, tør folk å svare» Hjelpeapparatets og politiets erfaringer med vold $i$ noere relasjoner $i$ samiske samfunn. Oslo, Norge: Nasjonalt kunnskapssenter om vold og traumatisk stress. 


\section{Takk}

Takk til Ristin Kemi, Eilif Nordvang og Torild Borud for inspirerande samtalar og nyttige innspel undervegs i dette arbeidet. Takk til kollegaer i hovudprosjektet 'Familieråd i fosterhjemsarbeid'. 